\title{
Alteration in Biochemical Constituents and Nutrients Partitioning of Asparagus Racemosus in Response to Elevated Atmospheric $\mathrm{CO} 2$ Concentration
}

\section{Rupali Sharma}

Forest Research Institute Dehradun

Hukum Singh ( $\nabla$ hukumsingh97@yahoo.com )

Forest Research Institute Dehradun https://orcid.org/0000-0003-2112-6182

\section{Research Article}

Keywords: Asparagus racemosus, biochemical response, nutrients, and carbon partitioning, elevated CO2 concentration

Posted Date: April 28th, 2021

DOl: https://doi.org/10.21203/rs.3.rs-317863/v1

License: (c) (1) This work is licensed under a Creative Commons Attribution 4.0 International License. Read Full License

Version of Record: A version of this preprint was published at Environmental Science and Pollution Research on August 30th, 2021. See the published version at https://doi.org/10.1007/s11356-021-160503. 
1 Title: Alteration in biochemical constituents and nutrients partitioning of Asparagus racemosus

2 in response to elevated atmospheric $\mathrm{CO}_{2}$ concentration

3 Running title: Biochemical and nutrients response of Asparagus racemosus against elevated $4 \quad \mathrm{CO}_{2}$ concentration

5 Authors:

6 Rupali Sharma

7 Forest Ecology and Climate change Division, Forest Research Institute, P.O. New Forest 8 Dehradun, 248006 (Uttarakhand) India.

9

10 Hukum Singh

11 Forest Ecology and Climate change Division, Forest Research Institute, P.O. New Forest 12 Dehradun, 248006 (Uttarakhand) India

13 ORCID: 0000-0003-2112-6182 
Alteration in biochemical constituents and nutrients partitioning of Asparagus racemosus in response to elevated atmospheric $\mathrm{CO}_{2}$ concentration

\begin{abstract}
Human-induced $\mathrm{CO}_{2}$ emissions since the preindustrial era have accumulated $\mathrm{CO}_{2}$ in the atmosphere which has influenced the plant structure and function including bio-chemical constituents of the plant system. The Himalayan vegetation has been predicted to be more vulnerable and sensitive to climate change. However, it is still not well documented that how atmospheric $\mathrm{CO}_{2}$ concentration will change the biochemical constituents considering nutrients status of Himalayan endangered plants in future climate change. Hence, we examined the impacts of elevated $\mathrm{CO}_{2}$ concentrations (ambient- $\sim 400,600$, and $800 \mu \mathrm{mol} \mathrm{CO}_{2} \mathrm{~mol}^{-1}$ ) on biochemical constituents (chlorophyll, carotenoids, ascorbic acid, protein, and total sugars and carbon partitioning) and nutrients response (potassium, phosphorus, and magnesium) in leaf, stem and root tissue of Asparagus racemosus Willd. (an endangered medicinal plant species of Himalayas). The results showed that the elevated $\mathrm{CO}_{2}$ concentration significantly $(\mathrm{p} \leq 0.05)$ enhanced the chlorophyll, protein, total sugars, and carbon accumulation conversely diminished ascorbic acid in leaf tissues. The nutrients accumulation especially potassium and magnesium were significantly $(\mathrm{p} \leq 0.05)$ improved while phosphorus accumulation suppressed under elevated $\mathrm{CO}_{2}$ concentration. Moreover, elevated $\mathrm{CO}_{2}$ notably altered protein, sugars, carbon, and nutrients partitioning in plant tissues viz. leaf, stem, and root of $A$. racemosus. The fate of rising atmospheric $\mathrm{CO}_{2}$ concentrations beyond $800 \mu \mathrm{mol} \mathrm{CO} \mathrm{mol}^{-1}$ will require much more study. Further studies are needed to understand the impacts of elevated $\mathrm{CO}_{2}$ concentration as well as a combination with other associated climatic variables on biochemical response particularly bioactive ingredients/health-promoting substances and nutrient profiling of this and other endangered medicinal plant species for improving livelihood support of the society.
\end{abstract}

Keywords: Asparagus racemosus, biochemical response, nutrients, and carbon partitioning, elevated $\mathrm{CO}_{2}$ concentration

\title{
Introduction
}

Climate change, a global phenomenon has got attention amongst scientific as well as political communities worldwide. It has already impacted the structure and function of the Earth's 
terrestrial system resulting in biodiversity change across the globe. Indian Himalayan Region (IHR), a biodiversity hotspot and repository of medicinal plants (Gangwar et al., 2010), is the most vulnerable and sensitive ecosystem to climate change (IPCC, 2007; Rana et al., 2015). Rising atmospheric $\mathrm{CO}_{2}$ concentration is an important climatic variable coupled to global climate change (IPCC, 2001). Atmospheric $\mathrm{CO}_{2}$ concentrations have been projected to reach $~ 475-1313$ $\mu \mathrm{mol} \mathrm{CO} \mathrm{mol}^{-1}$ by end of the 2100 (IPCC, 2013). The fertilization effect of risen atmospheric $\mathrm{CO}_{2}$ concentration on physiology, growth, and morphology ensuing productivity of the diverse crops species has been advocated by various researchers globally due to increased carbon assimilation (Cha et al., 2017; Singh et al., 2018; Sharma et al., 2018; Yadav et al., 2019; Ahammed et al., 2020). However, literature pointed out that the response of medicinal plants towards projected climatic variables particularly elevated $\mathrm{CO}_{2}$ concentrations has not been explored much more for the understanding response - feedback mechanism under climate change scenario (Applequist et al., 2020). Although, few experiments on medicinal plants suggested a profound impact on growth, physiology, productivity, and chemical substances including health-promoting substances or primary and secondary metabolites within elevated $\mathrm{CO}_{2}$ concentration (Zobayed and Saxena, 2004; Ziska et al., 2008; Moghaddam et al., 2011; Ghasemzadeh and Jaafar 2011a; Ghasemzadeh and Jaafar 2011b; Jaafar et al., 2012; Saldanha et al., 2014; Al Jaouni et al., 2018; Kaundal et al., 2018). Moreover, small accounts of the investigation focused on change in biochemical constituents and nutrients in leaf tissues of medicinal plants (Myers et al., 2014; Fernando et al., 2015; Broberg et al., 2017; Jayawardena et al., 2017; Kumar et al., 2020), conversably partitioning or allocation of biochemical compounds and nutrients to the plant's parts such as leaf, stem and root tissues in response to elevated $\mathrm{CO}_{2}$ concentration has neglected (Sutter et al., 2002; Aranjuelo et al., 2013; Aljazairi et al., 2014; Butterly, 2015; Thompson et al., 2017; Wang et al., 2019). Notably increased productivity of the foxglove was accounted for the plants grown under elevated $\mathrm{CO}_{2}$ concentration (Stuhlfauth et al., (1987; Stuhlfauth and Fock, 1990). After a decade, the plants of spider lily grown at 400 and 700 ppm produced $40 \%$ and 56\% more above and belowground biomass, respectively (Idso et al., 2000). Later, an experiment performed on the influence of $\mathrm{CO}_{2}$ concentration on growth and productivity of Hypericum perforatum, a medicinal plant species to Europe and West Asia was witnessed to a significant increment in biomass production (Zobayed and Saxena, 2004; Mosaleeyanon et al., 2005). Further studies conducted with few medicinal plant species viz. 
Nicotiana species and Datura stramonium (Ziska et al., 2005), Panax ginseng (Ali et al., 2005), Hizikia fusiforme (Zou, 2005), Papaver setigerum (Ziska et al., 2008), Thymus vulgaris(Vurro et al., 2009), Podophyllum hexandrum (Chaturvedi et al., 2009), Vernonia herbacea (Oliveira et al., 2010), Zingiber officinale (Ghasemzadeh and Jaafar, 2011a), Centella asiatica (Moghaddam et al., 2011), Elaeis guineensis (Ibrahim and Jaafar, 2012), Labisia pumila (Ibrahim et al., 2014), Catharanthus roseus (Saravanan and Karthi, 2014; Thinh et al., 2017), Withania sominifera (Sharma et al., 2018) have revealed a significant improvement in productivity and secondary metabolites of the plant system. In these studies, partitioning of biochemical ingredients and nutrients in plant tissues in response to elevated concentration of atmospheric $\mathrm{CO}_{2}$ has not studied. Although, few above studied medicinal plant species belong to the Himalayan region.

Hence, in a wake of predicted climate change especially rising elevated atmospheric $\mathrm{CO}_{2}$ medicinal plants of the Himalayan region requires much more exploration for food and health security and livelihood support of the community. The effect of climate change on the growth and production of secondary chemicals, biochemical constituents, and nutrients medicinal plants of IHR is still unclear and needs assessment (Gairola et al., 2010).

The effect of elevated $\mathrm{CO}_{2}$ on nutrients contents of plants is contradictory with increased, decreased or no effects. Nitrogen content in plant tissues has demonstrated decreased trend under elevated $\mathrm{CO}_{2}$ concentration (Cotrufo et al., 1998; Taub and Wang 2008) is the result of the carbohydrate dilution (Loladze, 2002) and the inhibition of nitrate assimilation in plant systems (Bloom et al., 2010). The response of nutrients accumulation in plants under elevated $\mathrm{CO}_{2}$ conditions has always been a debatable equation. The influence of elevated $\mathrm{CO}_{2}$ on the phosphorus accumulation in plants has always been more changeable than nitrogen with the confirmation for declined (Teng et al., 2006), increased (Liu et al., 2012) as well as no effects on plant phosphorus (Johnson et al., 2004). Based on the meta-analysis, Duval et al (2012) reported that the response of phosphorus in plants system under elevated $\mathrm{CO}_{2}$ concentration varied which depends on plant functional groups and other climatic as well as soil conditions, besides elevated $\mathrm{CO}_{2}$ concentration (Huang et al., 2015).

Elevated $\mathrm{CO}_{2}$ generally induced accumulation of biochemical constituents such as chlorophyll, protein, total sugars, and carbon in plant tissues along with little evidence for decreased or neutral or no effects on these bio-chemicals. Dong et al (2018) in his meta-analysis showed 
increasing and decreasing content of chlorophyll, ascorbic acid, total sugars, etc in various plant tissues. It has been investigated that elevated $\mathrm{CO}_{2}$ can diminish the photorespiration process of the plant system. Reduced photorespiration might subsequently diminish the formation of oxygen radicals, hence dipping antioxidant metabolism (Pérez-López et al., 2018). Wu et al (2017) stated that elevated $\mathrm{CO}_{2}$ concentration may influence the accumulation of antioxidants especially ascorbic acid via a complex mechanism considering the synthesis, recycling, and ascorbic acid's degradation hence decreasing ascorbic acid content in plant tissues.

Asparagus racemosus Willd. (Shatavari), an important medicinal plant species are used for curing various diseases since the ancient era. Due to higher medicinal value, it has occupied an important place in various parts of literature mainly Ayurvedic, Unani, and African traditional medicines. Because of importance in the literature, A. racemosus is leading a huge demand amongst local, national, and international markets (Mirjalili et al., 2009; Prajapati et al., 2003). A. racemosus has got endangered status by IUCN in India due to overexploitation, deforestation, and degradation in addition to climate change. It is one of the important medicinal plants of IHRwhich has been prioritized top eight medicinal plant species by the National Medicinal Plant Board, Government of India.

The alteration in biochemical compounds/constituents and nutrients partitioning in plant tissues of A. racemosus has not been investigated yet to understand how A. racemosus respond to climate change mainly elevated $\mathrm{CO}_{2}$ concentrations. To address this gap, the present study was to investigate the variation in biochemical constituents and nutrients partitioning in leaf, stem, and root parts of Asparagus racemosus in response to elevated atmospheric $\mathrm{CO}_{2}$ concentrations. We hypothesized what the climate change could make possible changes in the plants wealth in relation to primary metabolites, biochemical constituents and nutrients partitioning.

\section{Materials and Methods}

\section{Brief of open-top chamber (OTC) facility}

We experimented within identical open-top chambers (OTCs) constructed at Forest Research Institute, Dehradun, Uttarakhand (32 $20^{\prime} 44.2172^{\prime \prime} \mathrm{N}, 78^{\circ} 0^{\prime} 41.6185^{\prime \prime} \mathrm{E}$ and 668 m.a.s.l.). Highquality multilayer polycarbonate sheet with $80-85 \%$ transmittance was used to construct opentop chambers with a dimension of $3 w \times 41 \times 41$ (Singh et al., 2018; Sharma et al., 2018). Pure (100\%) $\mathrm{CO}_{2}$ gas of commercial-grade was supplied from the $\mathrm{CO}_{2}$ gas cylinder to the respective 
OTCs which was regulated by PC linked Program Logic Control (PLC) system and Supervisory Control and Data Acquisition (SCADA) system. The $\mathrm{CO}_{2}$ was supplied from 09:00 am to 05:00 pm during the study period by considering enough sunlight is available during between this duration.

\section{Seedlings preparation of Asparagus racemosus}

The five-month-old seedlings of A. racemosus gained obtained from Non-Wood Forest Product Division, Forest Research Institute, Dehradun. The healthy seedlings were transplanted in earthen pots with a proper growing medium of soil: sand: manure (2:2:1). The potted seedlings were left within and outside open-top chambers (OTCs) for one week to acclimatize the conditions. The experiment was laid out in Completely Randomized Design with four $\mathrm{CO}_{2}$ treatments viz. 600, $800,1000,1200 \mu \mathrm{mol} \mathrm{mol}^{-1} \mathrm{CO}_{2}$ in addition to control. Five replications were considered with eight seedlings per replication $(\mathrm{N}=40)$.

\section{$\mathrm{CO}_{2}$ treatments}

After a week, a set of eight potted seedlings were placed within OTCs with replication to grow under elevated $\mathrm{CO}_{2}$ concentration $\left(600 \pm 12\right.$ and $\left.800 \pm 16 \mu \mathrm{mol} \mathrm{mol}^{-1}\right)$ in addition to ambient OTCs conditions without $\mathrm{CO}_{2}$ treatments. The proper watering and weeding of pots were done during the study period of the six months.

\section{Measurement of biochemical constituents and biomass estimation of plant tissues}

The biochemical constituents were analyzed from leaf and root tissues at reproductive as well as the maturity phase. The healthy leaves and root tissues were preferred for analyzing biochemical parameters from the upper, middle, and lower parts of the plants. Leaf (LPROT) and root protein (RPROT) estimation was done by the method of Bradford (1976). Fresh tissues were taken from each plant and kept in icebox to prevent denaturation of protein while bringing to the laboratory. Leaf sample $(100 \mathrm{mg})$ was homogenized with $1 \mathrm{ml}$ phosphate buffer over an ice tray. The homogenate was then centrifuged at $13000 \mathrm{rpm}$ at $4^{\circ} \mathrm{C}$ for 20 minutes. Then, phosphate buffer $(5 \mathrm{ml})$ was added to the supernatant. After that, $0.5 \mathrm{ml}$ of this mixture was taken and made to $1 \mathrm{ml}$ with phosphate buffer. Bradford dye $(3 \mathrm{ml})$ was added to the above solution and it was kept at room temperature for 25 minutes for the completion of the reaction. Optical density was measured at $595 \mathrm{~nm}$ against a blank containing $3 \mathrm{ml}$ Bradford reagent and $1 \mathrm{ml}$ phosphate buffer. Different concentrations of bovine serum albumin (BSA) were taken for obtaining the standard 
curve. Protein concentration in the sample was then estimated using a linear equation of the BSA standard curve.

Total sugars from leaf (TLS) and root (RLS) tissues were determined as per the method of Dubios et al. (1956). Separate solutions of 5\% phenol and $80 \%$ ethanol were prepared using distilled water. Separate samples $(100 \mathrm{mg})$ of fresh and fully expanded leaves and healthy root tissues from each plant were chopped into small pieces and placed in a graduated test tube prefilled with $5 \mathrm{ml}$ of $80 \%$ ethanol and subsequently incubated for one hour at $80^{\circ} \mathrm{C}$. Afterward, $0.5 \mathrm{ml}$ of this sample extract was taken in another test tube and further added $0.5 \mathrm{ml}$ distilled water (DW). After that, $5 \%$ phenol $(1 \mathrm{ml})$ was added to the above solution and incubated for an hour at room temperature. After an hour, $2.5 \mathrm{ml}$ of concentrated $\mathrm{H}_{2} \mathrm{SO}_{4}$ was added by keeping the samples on ice-tray and the reaction mixture was shaken well in an orbital shaker for a few seconds. The optical density was read at $490 \mathrm{~nm}$ against a blank containing $0.5 \mathrm{ml}$ ethanol, $0.5 \mathrm{ml}$ DW, $1 \mathrm{ml} 5 \%$ phenol, and $2.5 \mathrm{ml}$ concentrated $\mathrm{H}_{2} \mathrm{SO}_{4}$. The standard curve was obtained by using different concentrations of Dextrose. The amount of total sugar in the sample was determined from the linear equation of the standard curve. The value obtained was multiplied by the dilution factor to obtain the total sugar concentration in terms of $\mu \mathrm{g} / \mathrm{mg}$ fresh weight of the sample.

Ascorbic acid (ASC), another indicator of stress in plants was estimated using the method developed by Harris and Ray's (1953). Fresh and fully expanded flag leaves from each plant were homogenized with $2 \mathrm{ml}$ of 4\% TCA and then centrifuged at 20,000 rpm for 10 minutes. In each centrifuged tube, a pinch of activated charcoal was added and again centrifuged at 12,000 rpm for 10 minutes to convert ascorbate to dehydroascorbate. A volume of supernatant $(0.5 \mathrm{ml} 0$ was taken into a test tube and then $1.5 \mathrm{ml}$ of $4 \%$ TCA was added immediately, followed by the addition of $0.5 \mathrm{ml} 2 \% \mathrm{DNPH}$ and 2 drops of $10 \%$ thiourea. The mixture was kept at $37^{\circ} \mathrm{C}$ for three hours for completion of the reaction. The reaction was terminated by placing the test tubes on an ice tray and then added $2.5 \mathrm{ml}$ of $\mathrm{H}_{2} \mathrm{SO}_{4}$ and left it at room temperature for 30 minutes, and the mixture produced orange colour. The optical density of orange colour mixture was read at $540 \mathrm{~nm}$ against a blank $\left(0.5 \mathrm{ml} \mathrm{DNPH}, 2\right.$ drops thiourea, and $2.5 \mathrm{ml}$ concentrated $\left.\mathrm{H}_{2} \mathrm{SO}_{4}\right)$. The Ascorbic acid content in the leaf tissue was determined by the standard curve equation obtained using different concentrations of pure ascorbic acid. The values obtained were multiplied by the dilution factor to get ascorbic acid content in leaf tissues and expressed as $\mu \mathrm{g} / 100 \mathrm{mg}$ fresh weight. 
Leaf chlorophyll content was estimated from fresh and healthy leaves as per the method described by Hiscox and Israelstam (1979). Fresh leaf tissues (50 mg) were chopped into the tiny pieces and then transferred into the test tubes containing $8 \mathrm{ml}$ of Dimethyl Sulfoxide (DMSO). Further, the tubes were incubated at $65{ }^{\circ} \mathrm{C}$ for three hours in the oven. The sample was afterward filtered into a graduated test tube and the volume was made to $10 \mathrm{ml}$ using DMSO. The absorbance of the samples was read at 663 and $645 \mathrm{~nm}$ against pure DMSO as a blank using spectrophotometer (Systronics Visiscan 167). Total leaf chlorophyll content ( $\mathrm{mg} \mathrm{g}^{-1}$ as fresh weight (F.W.)) was calculated using the following equation;

$$
\begin{aligned}
& \text { Chlorophyll a, Chl a }\left(\mathrm{mg} \mathrm{g}^{-1} \text { as } F . W .\right)=\frac{12.7 A_{663}-2.69 A_{645}}{w \times 1000} \\
& \text { Chlorophyll b, Chl b }\left(\mathrm{mg} \mathrm{g}^{-1} \text { as } F . W .\right)=\frac{22.9 A_{663}-4.68 A_{645}}{w \times 1000}
\end{aligned}
$$

$$
\text { Total leaf Chlorophyll, TChl }\left(\mathrm{mg} \mathrm{g}^{-1} \text { as F.W. }\right)=\frac{\left[\left(20.2 \times A_{645}\right)+\left(8.02 \times A_{663}\right) \times V\right]}{a \times 1000 \times w}
$$

Where; $A_{645}$ and $A_{663}$ - O. D. values measured at $645 \mathrm{~nm}$ and $663 \mathrm{~nm}$, respectively. V- Final volume of extract, a - path length of the cells $(1 \mathrm{~cm})$, and $\mathrm{w}$ - the weight of the leaf tissues taken. For estimating total leaf carotenoids content, the absorbance of samples was taken at $470 \mathrm{~nm}$ using a spectrophotometer. The below equation was adopted for calculating total carotenoids (Car) in leaf tissues ( $\mu \mathrm{g} \mathrm{g}^{-1}$ as fresh weight (F.W.));

$$
\text { Carotenoids content, } C A R\left(\mu g g^{-1} \text { as F.W. }\right)=\frac{1000 A_{470}-1.9\left(C h l_{a}-C h l_{b}\right)}{214}
$$

Biomass allocation in plant parts was calculated by carefully uprooting the plants and segregating into different parts leaves, stems, and root. The roots were cleaned with distilled water to remove particles sticking to root hairs. The fresh plant parts were weighed and subsequently oven dried at $65^{\circ} \mathrm{C}$ until a constant weight reached and weighed again (Wu et al., 2013; Singh et al., 2018).

\section{Estimation of nutrients accumulation}

Estimation of phosphorus $(\mathrm{P})$, potassium $(\mathrm{K})$, and magnesium $(\mathrm{Mg})$ in plant tissues especially leaf, stem, and root tissues was done after harvesting of the plants. The considered nutrients were estimated as per the procedure of Holman (1943), Morwin and Peach (1951), Young, and Gill (1951), respectively. The tri-acid solution, nitric acid $\left(\mathrm{HNO}_{3}\right)$, perchloric acid $\left(\mathrm{HClO}_{4}\right)$ and 
sulphuric acid $\left(\mathrm{H}_{2} \mathrm{SO}_{4}\right)$ in the ratio10:4:1 was used for preparing a stock solution. This stock solution was further used for estimating selected nutrients in plant tissues.

Phosphorus content was estimated as per the method described by Holman (1943). The reagents i.e. molybdate solution, hydrazine sulfate solution, and sodium hydroxide solution were used for further process of phosphorus estimation. Molybdate solution was prepared by adding $12.5 \mathrm{gm}$ of ammonium molybdate in $150 \mathrm{ml}$ of DW. $\mathrm{H}_{2} \mathrm{SO}_{4}(140 \mathrm{ml})$ was mixed in $150 \mathrm{ml}$ of DW and added to the above solution. Hydrazine sulfate (HS) solution was prepared by adding $0.15 \mathrm{gm}$ of HS to $100 \mathrm{ml}$ of DW. $\mathrm{NaOH}(45 \mathrm{gm})$ was mixed in $100 \mathrm{ml} \mathrm{DW}$ to make $\mathrm{NaOH}$ solution. Then, $2 \mathrm{ml}$ of stock solution was mixed with $10 \mathrm{ml} \mathrm{DW}$ in a $100 \mathrm{ml}$ flask. After that, 1 to 2 drops of phenolphthalein were added and the mixture was titrated against $\mathrm{NaOH}$ solution till the reaction is completed and until the appearance of pink color. Now, $10 \mathrm{ml}$ of ammonium molybdate solution was added followed by a $2 \mathrm{ml}$ HS solution. The volume of the mixture was made to $100 \mathrm{ml}$ by adding DW. The flasks were incubated in a boiling water bath for 15 minutes to complete the reaction. The optical density of this solution was measured at 830nm.

$$
\text { Phosphorus }(\%)=\frac{\text { O. D. } \times \text { Volume } \times 100}{10^{6} \times \text { Weight of plant tissues }}
$$

Potassium content in plant tissues was determined using the method described by Vogel, (1961). For potassium content, $2 \mathrm{ml}$ of stock solution was mixed in $100 \mathrm{ml}$ of DW in a $100 \mathrm{ml}$ conical flask. The flame photometer (Systronics flame photometer 128) was calibrated with DW at $100 \mathrm{ppm}$ and 40ppm standard potassium solutions. The readings were taken for each sample and the calculations were done as follows;

$$
\text { Potassium }(\%)=\frac{\text { O. D. } \times \text { Volume } \times 100}{10^{6} \times \text { Weight of plant tissues }}
$$

For magnesium, $2 \mathrm{ml}$ of the stock solution was added in a $50 \mathrm{ml}$ flask. Then, $10 \mathrm{ml}$ of distilled water was added to it followed by $2 \mathrm{ml}$ of the compensatory solution, $2 \mathrm{ml}$ of $2 \%$ polyvinyl alcohol (PVA), $1 \mathrm{ml}$ of hydroxylamine hydrochloride, $1 \mathrm{ml}$ titan yellow solution and $45 \%$ sodium hydroxide. The net volume was made $50 \mathrm{ml}$ with distilled water (light orange colour appeared). The absorbance of the sample with blank was measured at $540 \mathrm{~nm}$ using the spectrophotometer (Systronics Visiscan 167). Organic carbon (OC) was estimated after harvesting of Asparagus racemosus from leaf (LOC), stem (SOC), and root (ROC) as per the standard procedure described by Walkley and Black (1934). 


\section{Statistical analysis}

Descriptive analysis (mean, median, standard deviation and standard error of mean) were performed in Microsoft excel. Statistical software SPSS 16.0 was used with a multivariate general linear model to observe the existence of significant mean difference in response of biochemical parameters and nutrients accumulation at set levels $\mathrm{CO}_{2}$ concentrations. Further post hoc Tukey test was performed to identify the homogeneous subsets. Coefficient of determination $\left(\mathrm{R}^{2}\right)$ was provided in supplementary table for all the studied parameters (Table 1). $\mathrm{CO}_{2}$ was considered as an independent variable and all studied parameters such as protein, total sugar, magnesium and so on were considered as dependent variables. Correlation analysis and Principal Component Analysis (PCA) was done through R studio statistical software. In the text, the term significant is used to indicate $p$-value $\leq 0.05$.

\section{Results}

\section{Effect of elevated $\mathrm{CO}_{2}$ on the biochemical response of plants}

Elevated $\mathrm{CO}_{2}$ significantly promoted leaf chlorophyll, total sugar, and protein accumulation whereas impeded the ascorbic acid and carotenoid content in response to elevated $\mathrm{CO}_{2}$ concentration (Fig. 1and 2). The study reported an increment of $\sim 5.12$ and $\sim 9.14$ (Chl "a"), $\sim 3.01$ and $\sim 5.57$ (Chl "b"), and $\sim 3.20$ and $\sim 6.81$ (TChl) for the plants grown at 600 and $800 \mu \mathrm{mol} \mathrm{CO}_{2}$ $\mathrm{mol}^{-1}$, respectively when compared to ambient grown plants (Fig. 1). Another studied important pigment i.e. carotenoid concentration significantly diminished along with the elevated $\mathrm{CO}_{2}$ concentration, which a reduction $\sim 2.97$ and $8.04 \%$ under elevated concentrations (600 and 800 $\mu$ mol $\mathrm{CO}_{2} \mathrm{~mol}^{-1}$ ) compared to counterparts (Fig. 1). Besides, elevated $\mathrm{CO}_{2}$ concentration had also enhanced leaf total sugar significantly by $\sim 35.21 \%$ and $\sim 46.67 \%$ of plants exposed to 600 and $800 \mu \mathrm{mol} \mathrm{CO} 2 \mathrm{~mol}^{-1}$ ), respectively (Fig. 2). Similarly, total sugars in root tissues enhanced by $105.49 \%\left(600 \mu \mathrm{mol} \mathrm{CO}_{2} \mathrm{~mol}^{-1}\right)$ and $320.44 \%\left(800 \mu \mathrm{mol} \mathrm{CO}_{2} \mathrm{~mol}^{-1}\right)$ than ambient (Fig. 2). It was very interesting to account that protein accumulation in leaf and root significantly improved under elevated $\mathrm{CO}_{2}$ concentration (Fig. 2). Leaf protein increased by $36.21 \%$ and $85.53 \%$ at 600 $\mu \mathrm{mol} \mathrm{CO} 2 \mathrm{~mol}^{-1}$ and 85.53 at $800 \mu \mathrm{mol} \mathrm{CO}_{2} \mathrm{~mol}^{-1}$, respectively. The root protein content boosted by $55.08 \%$ and $91.68 \%$ at 600 and $800 \mu \mathrm{mol} \mathrm{CO}_{2} \mathrm{~mol}^{-1}$ grown plants (Fig. 2). Elevated $\mathrm{CO}_{2}$ suppressed ascorbic acid significantly in leaf tissues by 3.57 and $29.32 \%$ at 600 and 800 $\mu$ mol CO${ }_{2}$ mol $^{-1}$, respectively compared to counterparts i.e. ambient (Fig. 2). 
Nutrients accumulation in leaf, stem and root tissue of plants under elevated $\mathrm{CO}_{2}$ concentration

Nutrients viz. phosphorus $(\mathrm{P})$, potassium $(\mathrm{K})$, and magnesium $(\mathrm{Mg})$ showed different responses towards increased $\mathrm{CO}_{2}$ concentrations. $\mathrm{K}$ and $\mathrm{Mg}$, macro, and micronutrient respectively significantly increased while $\mathrm{P}$ (macro) decreased in response to elevated $\mathrm{CO}_{2}$ conditions than ambient grown plants (Fig. 3). The allocation of $\mathrm{K}$ to root, stem, and leaf tissues were profoundly altered by elevated $\mathrm{CO}_{2}$ with more allocation towards stem followed by leaf and root tissues. K exhibited variation in different plant tissues more allocation in all the tissues. Leaf $\mathrm{K}$ was significantly increased by $26.02 \%$ and $34.15 \%$ at 600 and $800 \mu \mathrm{mol} \mathrm{CO}_{2} \mathrm{~mol}^{-1}$, respectively compared to ambient plants (Fig. 3). Simultaneously, K content in stem tissues was significantly enhanced by 8.16 and $14.29 \%$ for plants grown under $\mathrm{CO}_{2}$ concentration of 600 and $800 \mu \mathrm{mol}$ $\mathrm{CO}_{2} \mathrm{~mol}^{-1}$, correspondingly rather than and root $\mathrm{K}$ enhanced by 18.41 and $34.58 \%$ at 600 and $800 \mu \mathrm{mol} \mathrm{CO} \mathrm{mol}^{-1}$, respectively (Fig. 3). $\mathrm{Mg}$, an important micronutrient of photosynthesis process accumulated more in leaves by 64.96 , and $69.03 \%$ of plants grown at 600 and $800 \mu \mathrm{mol}$ $\mathrm{CO}_{2} \mathrm{~mol}^{-1}$, respectively compared to ambient (Fig. 3). Likewise, magnesium $(\mathrm{Mg}$ ) in the stem was demonstrated better improvement of 39.89 and $182.03 \%$ at elevated $\mathrm{CO}_{2}$ of 600 and 800 $\mu \mathrm{mol} \mathrm{CO} 2 \mathrm{~mol}^{-1}$, respectively, whilst compared to ambient (Fig. 3). Furthermore, Mg content in root tissues was higher than leaves and stem, with an increment of 60.62 and $155.04 \%$ at 600 and $800 \mu \mathrm{mol} \mathrm{CO} \mathrm{mol}^{-1}$ and 155.04 rather than ambient (Fig. 3). Also, the magnesium was allocated to root followed by stem and leaf, however, phosphorus appeared to be the opposite with the above trend where the higher proportion was partitioned in leaf followed by root and stem tissues (Fig. 3). Leaf $\mathrm{P}$ was found to be decreased significantly by $29.79 \%$ at $600 \mu \mathrm{mol} \mathrm{CO} \mathrm{mol}^{-1}$ and $39.89 \%$ at $800 \mu \mathrm{mol} \mathrm{CO} \mathrm{mol}^{-1}$, likewise stem P reduced by $23.50 \%$ and $34.97 \%$ at 600 and 800 $\mu \mathrm{mol} \mathrm{CO} 2 \mathrm{~mol}^{-1}$, respectively compared to ambient $\mathrm{CO}_{2}$ conditions (Fig. 3). A similar trend has existed for root $\mathrm{P}$ with an increment of 43.69 and $55.31 \%$ at 600 and $800 \mu \mathrm{mol} \mathrm{CO} \mathrm{mol}^{-1}$, respectively (Fig. 3).

The response of organic carbon and biomass content in leaf, stem, and tissues under elevated $\mathrm{CO}_{2}$ concentration

Carbon is a vital element for fostering plant growth and development. Under the present study, elevated $\mathrm{CO}_{2}$ had significantly impacted carbon content and allocation in plant tissues such as 
312 leaf, stem, and root. The organic carbon (OC) content was reported to be enhanced across the 313 tissues (leaf, stem and root) under elevated $\mathrm{CO}_{2}$ circumstances (Fig. 2). Elevated $\mathrm{CO}_{2}$ induced 314 allocations of more carbon to the leaf tissues followed by stem and root for the plants grown at $315800 \mu \mathrm{mol} \mathrm{CO} 2 \mathrm{~mol}^{-1}$ in contrast, at $600 \mu \mathrm{mol} \mathrm{CO} \mathrm{mol}^{-1}$ more organic carbon allocation was 316 documented in stem followed by root and leaf (Fig. 2). Leaf and stem organic carbon was 317 reported significantly higher under elevated $\mathrm{CO}_{2}$ concentration compared to ambient grown 318 plants (Fig. 3). Similarly, a significant increment in root organic carbon was reported at elevated $319 \mathrm{CO}_{2}$ concentration when compared to ambient grown plants (Fig. 3).

320 concentrations

321 There was a uniform accumulation of dry matter grown under elevated $\mathrm{CO}_{2}$ concentration 322 recorded for all plants. The magnitude of percent increase in dry biomass was $28.27(\%)$ and $32350.48(\%)$ at 600 and $800 \mu \mathrm{mol} \mathrm{CO} 2 \mathrm{~mol}^{-1}$, respectively when compared to ambient. A significant 324 enhancement was noted in the stem, leaf and root dry biomass when exposed to elevated $\mathrm{CO}_{2}$ 325 concentrations (Fig. 4).

\section{The relationship amongst biochemical constituents and nutrients of plant tissues}

More than half of the traits studies represented a significant correlation between biochemical parameters and nutrients (Fig. 5). We observed a strong correlation between total chlorophyll, root protein $(r=0.89)$, leaf protein $(r=0.94)$, leaf organic carbon $(r=0.97)$, root organic carbon $(r=0.94)$, root magnesium $(r=0.87)$ and root potassium $(r=0.75)$. Interestingly, root organic carbon and root protein were significantly correlated $(r=0.92)$. Principal component analysis (PCA) demonstrated more contribution of two principal components viz. PC1 and PC2 which contributed approximately 70 and $7 \%$, respectively through analyzing the magnitude and directions of the coefficients (Fig. 6).

\section{Discussion}

\section{Effect of elevated $\mathrm{CO}_{2}$ on the biochemical response of plants}

During external stress the carbon fixation is not allocated to growth function despite it is directed to secondary metabolites production since growth is inhibited to photosynthesis (Mooney et al., 1991). Thus, elevated $\mathrm{CO}_{2}$ modified the biochemical accumulation in plants to adjust with 
present conditions. Under the present study, chlorophyll content was increased under elevated carbon dioxide up to $800 \mu \mathrm{mol} \mathrm{CO} \mathrm{mol}^{-1}$ when compared to ambient. Increased chlorophyll is associated with the photosynthesis process. During photosynthesis, chlorophyll absorbs energy from sunlight while staying down at the thylakoid membrane of chloroplast which facilitates photosynthesis ultimately carbohydrates production and growth of the plant system. The increase in total chlorophyll content under elevated carbon dioxide was reported in previous studies conducted with Medicago sativa (Sgherri et al., 1998), x Mokara species (Gouk et al., 1999), Gycine max, Pennisetum glaucum, Chenopodium album, and Amaranthus retroflexus (Hamid et al., 2012), Raphanus raphanistrum (Urbonaviciute et al., 2006), Catharanthus roseus (Singh and Agarwal, 2015) and Acrocomia aculeata (Rosa et al., 2019). Increased accumulation of primary metabolites i.e. protein, total sugar, etc contributed towards secondary metabolite production by providing building blocks and biosynthetic enzymes that were procured from primary metabolites. The study reported an increase in total sugar content which directly proportional to an increase in physiological parameters (Fig. 5). It has been reported that elevated $\mathrm{CO}_{2}$ concentration induced to increase triose phosphate of leaves that further contribute to the formation of carbohydrates resulting in more sugar accumulation, as we reported in the present study. Various studies are witnessed to increase total sugar content in plants such as viz. Labisia pumila (Ibrahim and Jaafar, 2011), Labisia pumila, and Catharanthus roseus (Saravanan and Karthi, 2014). Protein helps to support plant structure which found to be increased under this study in response to elevated $\mathrm{CO}_{2}$ concentration. In support, increased protein content under elevated $\mathrm{CO}_{2}$ was reported by researchers in Oryza sativa and Chaetoceros gracilis (Liu et al., 2017; Khairy et al., 2014). There is no satisfactory explanation until now for such an increase nevertheless; such an increase can be justified with the fact of protein linkage to nitrogen content (Hocking and Meyer, 1991). Ascorbic acid was reduced under exposure to elevated carbon dioxide and such suppression supported by Azam et al. (2017) on Capsicum annuum grown within elevated carbon dioxide concentration up to $1000 \mu \mathrm{mol} \mathrm{CO} 2 \mathrm{~mol}^{-1}$. Contradictory, few studies reported increased ascorbic acid under higher $\mathrm{CO}_{2}$ concentrations, yet a study on transcript profile on genes of carrot justified the occurrence of a complex process that degrades the ascorbic acid (Dong et al., 2018). The meta-analysis performed by Dong et al. (2018) suggested an increment or decline in chlorophyll, ascorbic acid, total sugars, in plant tissues. Elevated $\mathrm{CO}_{2}$ generally declines the photorespiration mechanism of the plants which further 
reduces the formation of oxygen radicals, consequently reducing antioxidant metabolism (PérezLópez et al., 2018). Wu et al (2017) stated that elevated $\mathrm{CO}_{2}$ concentration may influence the accumulation of antioxidants especially ascorbic acid via a complex mechanism considering the synthesis, recycling, and ascorbic acid's degradation hence decreasing ascorbic acid content in plant tissues.

\section{Nutrients accumulation in leaf, stem and root tissue of plants under elevated $\mathrm{CO}_{2}$ concentration}

Essential nutrients, whose limitation hinders the process of growth and survival since they are paramount of generating new cells, respond differently under elevated carbon dioxide concentrations. $\mathrm{K}$ regulates the carbon uptake process, along with photosynthesis, and stomatal conductance and increase of $\mathrm{k}$ generally help in better response likewise, $\mathrm{Mg}$ is a heart of chlorophyll and it helps in plants capturing more sunlight for performing photosynthesis process. $\mathrm{K}$ and $\mathrm{Mg}$ content was increased in both species studied under elevated carbon dioxide concentrations which led to enhancement physiological processes like transpiration rate and stomatal conductance might be the reason for an increase in $\mathrm{K}$ and $\mathrm{Mg}$ under elevated $\mathrm{CO}_{2}$ concentration which increases uptake rate of nutrients from the soil system. Such a trend was in Picea abies (Sallas et al., 2003) and O. sativa (Seneweera, 2011) for those plants exposed to high $\mathrm{CO}_{2}$ levels. The study depicted a decrease in $\mathrm{P}$ content in plant tissues under elevated $\mathrm{CO}_{2}$ concentrations. The reduction in $\mathrm{P}$ might be due to high carbohydrate in plant tissues which results in more biomass production and further contributes to the mechanism of dilution effect (Dong et al., 2018). Such a decrease in P content was reported in Lactuca sativa and Spinacia oleracea under elevated $\mathrm{CO}_{2}$ concentration (Giri et al., 2016). The effect of increased $\mathrm{CO}_{2}$ concentration on nutrients of plant tissues has been always considered as the debatable research question. Nutrients concentration was reported to be increasing, decreasing, and no effect in response to elevated $\mathrm{CO}_{2}$ concentration in plant species. Nitrogen content in plant tissues has demonstrated decreased trend under elevated $\mathrm{CO}_{2}$ concentration (Cotrufo et al., 1998; Taub and Wang, 2008) is the result of the carbohydrate dilution (Loladze, 2002) and the inhibition of nitrate assimilation in plant systems (Bloom et al., 2010). The influence of elevated $\mathrm{CO}_{2}$ on the $\mathrm{P}$ accumulation in plants has always been more changeable than nitrogen with the confirmation for declined (Teng et al., 2006), increased (Liu et al., 2012) as well as no effects on plant P (Johnson et al., 2004). A study performed using meta-analysis found reported decreased $\mathrm{P}$ in plants in 
402

403

404

405

406

407

408

409

410

411

412

413

414

415

416

417

418

419

420

421

422

423

424

425

426

427

428

429

430

431

response to elevated $\mathrm{CO}_{2}$ concentration which depends on plant functional groups and other climatic circumstances (Duval et al., 2012), besides elevated $\mathrm{CO}_{2}$ concentration (Huang et al., 2015).

\section{The response of organic carbon and biomass accumulation in leaf, stem, and tissues under elevated $\mathrm{CO}_{2}$ concentration}

In the present study, elevated $\mathrm{CO}_{2}$ had altered carbon allocation to the plant's tissues such as leaf, stem, and root under elevated $\mathrm{CO}_{2}$ concentration. The plants grown at $600 \mu \mathrm{mol} \mathrm{CO}_{2} \mathrm{~mol}^{-1}$ allocated more carbon towards stem followed by root, and leaf whereas more allocation to leaf followed by the stem, and root tissues at $800 \mu \mathrm{mol} \mathrm{CO} \mathrm{mol}^{-1}$. This trend explained that 800 $\mu \mathrm{mol} \mathrm{CO}_{2} \mathrm{~mol}^{-1}$ slows the partitioning mechanism of carbon. The transfer of carbon to root tissues may require extended duration, besides other causes, it would be the long time required for the root kinetics mechanism of sequestering nutrients. However, the exact mechanism needs to be studied in the future to illustrate the mechanism of carbon allocation concerning time. Increase in carbon allocation to leaves, stem and root tissues under elevated $\mathrm{CO}_{2}$ condition was supported by Jeong et al. (2018) who performed a study on the same aspect with Hibiscus hambo, Paliurus ramosissimus, Cicuta virosa, Bupleurum latissimum, Viola raddeana, Iris dichotoma and Lavanya et al. (2017) on Morus species. The increase and decrease in biomass content varies from species to species. During the process of photosynthesis the plants absorb carbon dioxide and results in increase the biomass content in Asparagus racemosus. Such biomass production and increase in leaf biomass stem biomass, root biomass and dry biomass under elevated levels of $\mathrm{CO}_{2}$ concentrations were also reported (Thinh et al., 2017; Saravanan and Karthi, 2014).

\section{Conclusion}

It is concluded that rising $\mathrm{CO}_{2}$ concentration is significantly induced alteration in biochemical constituents and nutrients allocation in plant tissues such as leaf, stem, and root of Asparagus racemosus. The biochemical constituents such as chlorophyll, protein, total sugars, and carbon accumulation increased although ascorbic acid diminished significantly. The nutrients viz potassium and magnesium improved while phosphorus suppressed significantly against elevated $\mathrm{CO}_{2}$ concentration. Further, protein, sugars, carbon, and nutrients allocation in plant tissues altered profoundly at elevated $\mathrm{CO}_{2}$ concentrations. In a nutshell, the Asparagus racemosus will 
adapt in future climate change particularly in rising atmospheric $\mathrm{CO}_{2}$ concentration by modulating biochemical mechanisms and nutrients partitioning. Further studies are required to explore the actual mechanism of accumulation of biochemical ingredients and nutrients allocation in plant tissues in future climate change. Besides, investigation on the accumulation of bioactive ingredients/health-promoting substances and nutrient profiling of endangered medicinal plant species of the Himalayan ecosystem for sustainable food and health security.

\section{Declarations}

Ethics approval and consent to participate: The study does not involve any ethical dimension. Hence, not applicable

\section{Consent for publication: Not applicable}

Availability of data and materials: The datasets used and/or analysed during the current study are available from the corresponding author on reasonable request.

Competing interests: The authors declare that they have no competing interests.

Funding: No funding was received for this study.

Authors' contributions: Rupali Sharma: Methodology; data curation and observations; statistical analysis; drafting; Hukum Singh: Conceptualization, methodology; data curation; writing and editing, supervision, the original draft; writing and reviewing.

\section{Acknowledgments}

The authors are very thankful to the Director, Forest Research Institute, Dehradun, for providing the facility to carry out the proposed study.

\section{Authors' information (optional)}

\section{References}

Ahammed, G.J., Li, X., Liu, A., and Chen, S. (2020). Physiological and Defense Responses of Tea Plants to Elevated $\mathrm{CO}_{2}$ : A Review. Front. Plant Sci11, 305. https://doi.org/10.3389/fpls.2020.00305

Al Jaouni, S., Saleh, A.M., Wadaan, M.A.M., Hozzein, W.N., Selim, S., and AbdElgawad, H. (2018). Elevated $\mathrm{CO}_{2}$ induces a global metabolic change in basil (Ocimum basilicum L.) and peppermint (Mentha piperita L.) and improves their biological activity. J Plant Physiol. 224-225, 121-131.doi: 10.1016/j.jplph.2018.03.016 
Ali, M. B., Hahn, E. J., and Paek, K. Y. (2005). $\mathrm{CO}_{2}$-induced total phenolics in suspension cultures of Panax ginseng C.A. Mayer roots: role of antioxidants and enzymes. Plant Physiol. Biochem 43, 449-457.

Aljazairi, S., Arias, C., and Nogues, S. (2014). Carbon and nitrogen allocation and partitioning in traditional and modern wheat genotypes under pre-industrial and future $\mathrm{CO}_{2}$ conditions. Plant Biol.17, 647-659. doi: 10.1111/plb.12280

Applequist, W.L., Brinckmann, J.A., Cunningham, A.B., Hart, R.E., Heinrich, M., Katerere, D.R.,et al. ( 2020). Scientists' Warning on Climate Change and Medicinal Plants.Planta Med 86, $10-18$.

Aranjuelo, I., Cabrerizo, P.M., Arrese-Igor, C., and Aparicio-Tejo, P.M. (2013). Pea plant responsiveness under elevated $\left[\mathrm{CO}_{2}\right]$ is conditioned by the $\mathrm{N}$ source $\left(\mathrm{N}_{2}\right.$ fixation versus $\mathrm{NO}_{3}$ fertilization). Environ. Exp. Bot.95, 34-40. doi.org/10.1016/j.envexpbot.2013.10.020

Azam, A., Hameed, A., and Khan, I. (2017). Impact of Elevated Atmospheric Carbon Dioxide on Yield, Vitamin C, Proximate, Fatty Acid and Amino Acid Composition of Capsicum (Capsicum Annuum). Environmental Pollution and Protection 2, 153-167. doi: 10.22606/epp.2017.24001

Bloom, A. J., Burger, M., Rubio-Asensio, J. S. and Cousins, A. B. 2010. Carbon dioxide enrichment inhibits nitrate assimilation in wheat and Arabidopsis. Science, 328: 899-903.

Broberg, M., Högy, P., and Pleijel, H. (2017). $\mathrm{CO}_{2}$-induced changes in wheat grain composition: meta-analysis and response functions. Agronomy 7, 32. doi: 10.3390/agronomy7020032

Butterly, C.R., Armstrong, R., Chen, D., and Tang, C. (2015). Carbon and nitrogen partitioning of wheat and field pea grown with two nitrogen levels under elevated $\mathrm{CO}_{2}$. Plant Soil 391, 367382. doi: 10.1007/s11104-015-2441-5

Cha, S., Chae, H.M., Lee, S.H., and Shim, J.K. (2017). Effect of elevated atmospheric $\mathrm{CO}_{2}$ concentration on growth and leaf litter decomposition of Quercus acutissima and Fraxinus rhynchophylla. PLoS ONE 12, e0171197.doi:10.1371/journal.pone.0171197. 
Chaturvedi, A. K., Vashistha, R. K., and Rawat, N. (2009). Effect of $\mathrm{CO}_{2}$ Enrichment on Photosynthetic Behavior of Podophyllum Hexandrum Royle, an Endangered Medicinal Herb. Journal of American Science 5, 113-118.

Cotrufo, M. F., Ineson, P. and Scott, A. 1998. Elevated $\mathrm{CO}_{2}$ reduces the nitrogen concentration of plant tissues. Glob. Change Biol. 4: 43-54.

Dong J., Gruda N., Lam S. K., Li. X and Duan Z. 2018. Effects of Elevated $\mathrm{CO}_{2}$ on Nutritional Quality of Vegetables: A Review. Front. Plant Sci. 9:924. DOI: 10.3389/fpls.2018.00924.

Dong, J., Gruda, N., Lam, S.K., Li, X., and Duan, Z. (2018). Effects of Elevated $\mathrm{CO}_{2}$ on Nutritional Quality of Vegetables: A Review. Front. Plant Sci. 9, 924. doi: 10.3389/fpls.2018.00924

Dubois, M., Gilles, K. A., Hamilton, J. K., Rebers, P. A., and Smith, F. (1956). Colorimetric method for determination of sugars and related substances. Anal. Chem. 28, 350-356.

Duval, B. D., Blankinship, J. C., Dijkstra, P. and Hungate, B. A. 2012. $\mathrm{CO}_{2}$ effects on plant nutrient concentration depend on plant functional group and available nitrogen: a meta-analysis. Plant Ecol. 213: 505-521.

Fernando, N., Panozzo, J., Tausz, M., Norton, R., Fitzgerald, G., Khan, A., et al. (2015). Rising $\mathrm{CO}_{2}$ concentration altered wheat grain proteome and flour rheological characteristics. Food Chem 170, 448-454. doi: 10.1016/j.foodchem.2014.07.044

Gairola, S., Shariff, N. M., Bhatt, A., and Kala, C. P. (2010).Influence of climate change on production of secondary chemicals in high altitude medicinal plants: Issues needs immediate attention. J. Med. Plant Res. 4, 1825-1829.

Gangwar, K.K., Deepali, K., and Gangwar, R. S. (2010). Ethnomedicinal plant diversity in Kumaun Himalaya of Uttarakhand, India. Nat.Sci.8, 66-78.

Ghasemzadeh, A., and Jaafar, H.Z.E. (2011a). Antioxidant potential and anticancer activity of young ginger (Zingiber officinale Roscoe) grown under different $\mathrm{CO}_{2}$ concentration. J. Med. Plants Res. 5, 3247-3255. 
512 Ghasemzadeh, A., and Jaafar, H.Z.E. (2011b). Effect of $\mathrm{CO}_{2}$ Enrichment on Synthesis of Some 513 Primary and Secondary Metabolites in Ginger (Zingiber officinale). Int. J. Mol. Sci. 12, 11015141114.

515 Giri, A., Armstrong, B., and Rajashekar, C.B. (2016). Elevated Carbon Dioxide Level 516 Suppresses Nutritional Quality of Lettuce and Spinach. Am. J. Plant Sci. 7, 246-258.

517 Gouk, S.S., He, J., and Hew, C.S. (1999). Changes in photosynthetic capability and 518 carbohydrate production in an epiphytic CAM orchid plantlet exposed to super-elevated $519 \mathrm{CO}_{2}$. Environ. Exp. Bot. 41, 219-230.

520 Hamid, R.M., Ahmad, R., and Ali, R.B. (2012). The impact of elevated $\mathrm{CO}_{2}$ on growth and 521 competitiveness of $\mathrm{C}_{3}$ and $\mathrm{C}_{4}$ crops and weeds. Euro. J. Exp. Bio. 2, 1144-1150.

522 Hiscox, J. D., and Israelstam, G. F. (1979). A method for the extraction of chlorophyll from leaf 523 tissue without maceration. Can. J. Bot. 57, 1332-1334.

524 Hocking, P. J., and Meyer, C. P. (1991). Carbon dioxide enrichment decreases critical nitrate and 525 nitrogen concentrations in wheat. J. Plant Nutr. 14, 571-584.

526 Holman, W. I. M. (1943). A new technique for the determination of phosphorus by the 527 molybdenum blue method. Biochem. J. 37, 256-259.

528 Huang, W., Houlton, B. Z., Marklein, A. R., Liu, J. and Zhou, G. 2015. Plant stoichiometric 529 responses to elevated $\mathrm{CO}_{2}$ vary with nitrogen and phosphorus inputs: Evidence from a global530 scale meta-analysis. Scientific Reports, 5:18225; DOI: 10.1038/srep18225.

531 Ibrahim, M .H ., and Jaafar, H.Z.E. (2011). Increased Carbon Dioxide concentration improves 532 the antioxidative properties of the Malaysian herb Kacip Fatimah (Labisia pumila). Molecules16, $533 \quad 6068-6081$.

534 Ibrahim, M.H., and Jaafar, H.Z.E. (2012). Impact of Elevated Carbon Dioxide on Primary, 535 Secondary Metabolites and Antioxidant Responses of Eleais guineensis Jacq. (Oil Palm) 536 Seedlings. Molecules17, 5195-5211. 
Ibrahim, M.H., Jaafar, H.Z.E., Karimi, E., and Ghasemzadeh, A. (2014). Allocation of Secondary Metabolites, Photosynthetic Capacity, and Antioxidant Activity of Kacip Fatimah (Labisia pumilaBenth) in Response to $\mathrm{CO}_{2}$ and Light Intensity. The Scientific World Journal, http://dx.doi.org/10.1155/2014/360290.

Idso, S.B., Kimball, B.A., Pettit III, G.R., Garner, L.C., Pettit, G.R. and Backhaus, R.A. (2000). Effects of atmospheric $\mathrm{CO}_{2}$ enrichment on the growth and development of Hymenocallis littoralis (Amaryllidaceae) and the concentrations of several antineoplastic and antiviral constituents of its bulbs. Am. J. Bot 87, 769-773.

IPCC, 2001: Climate Change 2001: The Scientific Basis. Contribution of Working Group I to Third Assessment Report of the Intergovernmental Panel on Climate Change. Cambridge University Press, Cambridge, United Kingdom and New York, NY, USA.

IPCC, 2007. Climate Change 2007: Impacts, Adaptation and Vulnerability. Contribution of Working Group II to Fourth Assessment Report of the Intergovernmental Panel on Climate Change. Cambridge University Press, Cambridge, United Kingdom and New York, NY, USA.

IPCC, 2013. Climate Change 2013: The Physical Science Basis. Contribution of Working Group I to the Fifth Assessment Report of the Intergovernmental Panel on Climate Change. Cambridge University Press, Cambridge, United Kingdom and New York, NY, USA.

Jaafar, H.Z.E., Ibrahim, M.H., and Karimi, E. (2012). Phenolics and flavonoids compounds, phenylanine ammonia lyase and antioxidant activity responses to elevatedCO $\mathrm{C}_{2}$ in Labisia pumila (Myrisinaceae). Molecules 17, 6331-6347.

Jayawardena, D. M., Heckathorn, S. A., Bista, D. R., Mishra, S., Boldt, J. K., and Krause, C. R. (2017). Elevated $\mathrm{CO}_{2}$ plus chronic warming reduce nitrogen uptake and levels or activities of nitrogen-uptake and -assimilatory proteins in tomato roots. Physiol. Plant. 159, 354-365. doi: $10.1111 / \mathrm{ppl} .12532$

Jeong, H. M., Kim, H.R., Hong, S., and Han,Y.(2018). Effects of elevated $\mathrm{CO}_{2}$ concentration and increased temperature on leaf quality responses of rare and endangered plants.J. Ecology. Environ. 42, 1. doi.org/10.1186/s41610-017-0061-0 
Johnson, D.W., Cheng, W., Joslin, J.D., Norby, R.J., Edwards, N.T. and Todd D.E. 2004. Effects of elevated $\mathrm{CO}_{2}$ on nutrient cycling in a sweetgum plantation. Biogeochemistry 69, 379-403. https://doi.org/10.1023/B:BIOG.0000031054.19158.7c

Kaundal, M., Bhatt, V., and Kumar, R. (2018). Elevated $\mathrm{CO}_{2}$ and temperature effect on essential oil content and composition of Valeriana jatamansi Jones. with organic manure application in a western Himalayan region. J. Essent. Oil Bear. Pl. 21, 10411050.doi.org/10.1080/0972060X.2018.1497547

Khairy, H.M., Shaltout, N. A., Naggar, M.F.El., and Naggar N.A.El. (2014). Impact of elevated $\mathrm{CO}_{2}$ concentrations on the growth and ultrastructure of non-calcifying marine diatom (Chaetoceros gracilis F.Schutt).Egypt. J. Aquat. Res. 40, 243250.doi.org/10.1016/j.ejar.2014.08.002

Kumar, R., Joshi, R., Kumari, M., Thakur, R., Kumar, D., and Kumar, S. (2020). Elevated $\mathrm{CO}_{2}$ and temperature influence key proteins and metabolites associated with photosynthesis, antioxidant and carbon metabolism in Picrorhiza kurroa. J. Proteomics219, 103755. doi:10.1016/j.jprot.2020.103755

Lavanya, C., Ashoka, J., Sreenivasa, A.G., Nadagoud, S., and Beladhadi B. V. (2017). Effect of Elevated Carbon Dioxide and Temperature on Growth, Yield and Quality Parameters of Mulberry. Int. J. Curr. Microbiol. App. Sci 6, 3351-3356. doi.org/10.20546/ijcmas.2017.611.393

Liu, J., Huang, W., Zhou, G., Zhang, D., Liu, S. and Li, Y. 2012. Nitrogen to phosphorus ratios of tree species in response to elevated carbon dioxide and nitrogen addition in subtropical forests. Glob. Change Biol. 19: 208-216.

Liu, S., Waqas, M. A., Wang, Sh., Xiong Xy., and Wan, Yf. (2017). Effects of increased levels of atmospheric $\mathrm{CO}_{2}$ and high temperatures on rice growth and quality. PLOS ONE 12: e0187724. https://doi.org/10.1371/journal.pone.0187724

Loladze, I. 2002. Rising atmospheric $\mathrm{CO}_{2}$ and human nutrition: toward globally imbalanced plant stoichiometry? Trends Ecol. Evol. 17: 457-461. 
Mirjalili, M. H., Moyano, E., Bonfill, M., Cusido, R. M., and Palazon, J. (2009). Steroidal lactones from Withania somnifera, an ancient plant for novel medicine. Molecules 14, 2373 2393.

Moghaddam, S.S., Jaafar, H.B., Aziz, M.A., Ibrahim, R., Rahmat, A.B., and Philip, E. (2011). Flavonoid and leaf gas exchange responses of Centella asiatica to acute gamma irradiation and carbon dioxide enrichment under controlled environment conditions. Molecules 16, 8930-8944.

Mooney, H.A., Winner, W.E., and Pell, E.J. (1991). Response of plants to multiple stresses. Academic Press, San Diego, California, USA.

Morwin, H. D., and Peach, P. M. (1951). Exchangeability of soil potassium in and, silt and clay fractions as influenced by the nature of complementary exchangeable cations. Soil Sci. Soc. Am. J. 15, 125-128.

Mosaleeyanon, K., Zobayed, S. M. A., Afreen, F., and Kozai, T. (2005). Relationships between net photosynthetic rate and secondary metabolite contents in St. John's wort. Plant Sci. 169, 523531.

Myers, S. S., Zanobetti, A., Kloog, I., Huybers, P., Leakey, A. D. B., Bloom, A. J., et al. (2014). Increasing $\mathrm{CO}_{2}$ threatens human nutrition. Nature 510, 139-142. doi: 10.1038/nature13179

Oliveira, V. F., Zaidan, L. B. P., Braga, M. R., Aidar, M. P. M., and Carvalho, M. A. M. (2010). Elevated $\mathrm{CO}_{2}$ atmosphere promotes plant growth and inulin production in the cerrado species Vernonia herbacea. Funct. Plant. Biol. 37, 223-231.

Pérez-López, U., Sgherri, C., Miranda-Apodaca, J., Micaelli, F., Lacuesta, M., Mena-Petite, A., et al. (2018). Concentration of phenolic compounds is increased in lettuce grown under high light intensity and elevated $\mathrm{CO}_{2}$. Plant Physiol. Biochem. 123, 233-241. DOI: 10.1016/j.plaphy.2017.12.010.

Prajapati, N. D., Purohit, S. S., Sharma, A. K., and Kumar, T. (2003). A handbook of medicinal plants: A complete source book. Jodhpur: Agrobios, India, pp 756.

Radford, P. J. (1967). Growth analysis formulae. Their use and abuse. Crop Sci. 7, 171-175. 
Rana, S. K., Oli, P. S., and Rana, H. K.(2015). Traditional botanical knowledge (TBK) on the use of medicinal plants in Sikles area, Nepal. Asian J. Plant Sci. Res. 5, 8-15.

Roe, J. H., and Kuther. (1961). Standard Methods in Clinical Chemistry Vol III, Seligson D (ed), Academic Press, New York, pp 35-37.

Rosa, B.L., Souza, J.P., and Pereira, E.G. (2019). Increased atmospheric $\mathrm{CO}_{2}$ changes the photosynthetic responses of Acrocomia aculeata (Arecaceae) to drought. Acta Bot. Bras 33, 486497. doi: 10.1590/0102-33062019abb0056

Saldanha, C. W., Otoni, C. G., Rocha, D.I., Cavatte, P.C., Detmann, K. da S.C., Tanaka, F.A.O., et al.(2014). $\mathrm{CO}_{2}$-enriched atmosphere and supporting material impact the growth, morphophysiology and ultrastructure of in vitro Brazilian-ginseng [Pfaffia glomerata (Spreng.) Pedersen] plantlets. Plant Cell Tiss. Organ Cult. 118, 87-99.doi10.1007/s11240-014-0464-X

Sallas, L., Luomala, E.M., Ultriainen, J., Kainulainen, P., and Holopainen, J.K. (2003). Contrasting effects of elevated carbon dioxide concentration and temperature on Rubisco activity, chlorophyll fluorescence, needle ultra structure and secondary metabolites in conifer seedlings. Tree Physiol 23, 97-108.

Saravanan,S., and Karthi, S. (2014). Effect of elevated $\mathrm{CO}_{2}$ on growth and biochemical changes in Catharanthus roseus - an valuable medicinal herb. World J. Pharm. Pharmaceuti. Sci. 3, 411422.

Seneweera, S. (2011). Effects of elevated $\mathrm{CO}_{2}$ on plant growth and nutrient partitioning of rice (Oryza sativa) at rapid tillering and physiological maturity. J. Plant Interact. 6, 3542.doi.org/10.1080/17429145.2010.513483

Sgherri, C.L.M., Quartacci, M.F., Menconi, M., Raschi, A., and Navari-Izzo, F. (1998). Interactions between drought and elevated $\mathrm{CO}_{2}$ on alfalfa plants. J. Plant Physiol. 152, $118-124$.

Sharma, R., Singh, H., Kaushik, M., Nautiyal, R., and Singh, O. (2018). Adaptive physiological, carbon portioning and biomass production of Withania somnifera (L.) Dunal grown under elevated $\mathrm{CO}_{2}$ regimes. 3 Biotech 8, 1-10. 
Singh, A., and Agarwal, M. (2015). Effects of ambient and elevated $\mathrm{CO}_{2}$ on growth, chlorophyll fluorescence, photosynthetic pigments, antioxidants, and secondary metabolites of Catharanthus roseus (L.) G Don. grown under three different soil N levels. Environ. Sci. Pollut. Res. Int. 22, 3936-3946. doi: 10.1007/s11356-014-3661-6

Singh, H., Sharma, R., Savita, A., Singh, M. P., Kumar, M., Verma, A., et al. (2018) Adaptive physiological response of Parthenium hysterophorus to elevated atmospheric $\mathrm{CO}_{2}$ concentration. Ind For 144, 1-14.

Stuhlfauth, T., and Fock, H.P. (1990). Effect of whole season $\mathrm{CO}_{2}$ enrichment on the cultivation of a medicinal plant, Digitalis lanata. J. Agron. Crop. Sci. 164, 168-173.

Stuhlfauth, T., Klug, K., and Fock, H.P. (1987). The production of secondary metabolites by Digitalis lanata during $\mathrm{CO}_{2}$ enrichment and water stress. Phytochemistry 26, 2735-2739.

Suter, D., Frehner, M., Fischer, B. U., Nösberger, J., and Lüsche, A. (2002). Elevated $\mathrm{CO}_{2}$ increases carbon allocation to the roots of Lolium perenne under free-air $\mathrm{CO}_{2}$ enrichment but not in a controlled environment. New Phytol. 154, 65-75. doi: 10.1046/j.1469-8137.2002.00 368.x

Taub, D. R. and Wang, X. Z. 2008. Why are nitrogen concentrations in plant tissues lower under elevated $\mathrm{CO}_{2}$ ? A critical examination of the hypotheses. J. Integr. Plant Biol 50: 1365-1374.

Teng, N., Wang, J., Chen, T., Wu, X., Wang, Y. and Lin, J. 2006. Elevated $\mathrm{CO}_{2}$ induces physiological, biochemical and structural changes in leaves of Arabidopsis thaliana. New Phytol. 172: 92-103.

Thinh, N. C., Shimono, H., Kumagai, E., and Kawasaki, M. (2017). Effects of elevated $\mathrm{CO}_{2}$ concentration on growth and photosynthesis of Chinese yam under different temperature regimes. Plant Prod. Sci. 20, 227-236.

Thompson, M., Gamage, D., Hirotsu, N., Martin, A., and Seneweera, S. (2017). Effects of Elevated Carbon Dioxide on Photosynthesis and Carbon Partitioning: A Perspective on Root Sugar Sensing and Hormonal Crosstalk. Front.Physiol 8, 578. doi: 10.3389/fphys.2017.00578 
Urbonaviciute, A., Samuoliene, G., Sakalauskaite, J., Duchovskis, P., Brazaityte, A., Siksnianiene, J.B., et al. (2006). The effect of elevated $\mathrm{CO}_{2}$ concentrations on leaf carbohydrate, chlorophyll contents and photosynthesis in radish. Pol. J. Environ. Stud. 15, 921-925.

Vurro, E., Bruni, R., Bianchi, A., and Sanità di Toppi, L. (2009). Elevated $\mathrm{CO}_{2}$ decreases oxidative stress and increases essential oil yield in leaves of Thymus vulgaris grown in a miniFACE system. Environ. Exper. Bot. 65, 99-107.

Wang, J., Liu, X., Zhang, X., Li, L., Lam, S.K., and Pan, G. (2019). Changes in plant C, N and P ratios under elevated $\left[\mathrm{CO}_{2}\right]$ and canopy warming in a rice-winter wheat rotation system. Sci. Rep 9, 5424. https://doi.org/10.1038/s41598-019-41944-1

Wu, X., Sun, S., Xing, G., Wang, G., Wang, F., Xu, Z., et al. (2017). Elevated carbon dioxide altered morphological and anatomical characteristics, ascorbic acid accumulation, and related gene expression during taproot development in carrots. Front. Plant Sci. 7:2026. DOI: 10.3389/fpls.2016.02026.

Young, H. Y., and Gill, R. F. (1951). Determination of magnesium in plant tissue with thiazole yellow. Anal. Chem. 23, 751-754.

Ziska, L.H., Panicker, S., and Wojno, H.L. (2008). Recent and projected increases in atmospheric carbon dioxide and the potential impacts on growth and alkaloid production in wild poppy (Papaver setigerum DC.). Clim. Change 91, 395-403

Ziska, L. H., Emche, S. D., Johnson, E. L., George, K., Reed, D. R., and Sicher. R. C. (2005). Alterations in the production and concentration of selected alkaloids as a function of rising atmospheric carbon dioxide and air temperature: Implications for ethnopharmacology. Glob. Chang. Biol. 11, 1798-1807.

Zobayed, S., and Saxena, P.K. (2004). Production of St. John's Wort plants under controlled environment for maximizing biomass and secondary metabolites. In Vitro Cell. Dev. Biol. Plant 40, 108-114.

Zou, D. H., and Gao, K. S. (2005). Regulation of gamete release in the economic brown seaweed Hizikia fusiformis (Phaeophyta). Biotechnol. Lett. 27, 915-918. 
Figures
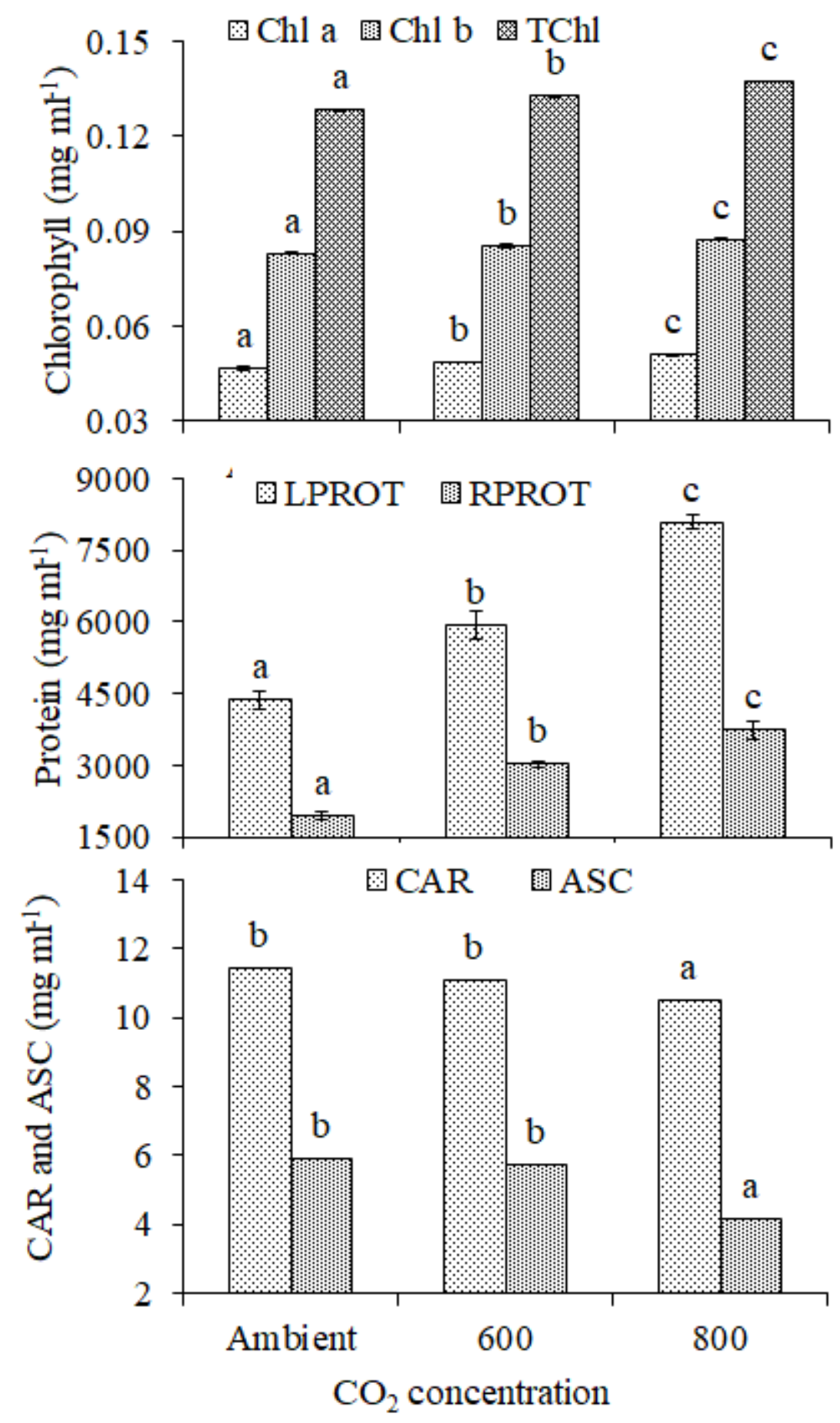

Figure 1

Effect of elevated $\mathrm{CO} 2$ concentration on chlorophyll (Chlorophyll a- Chla, Chlorophyll b- Chlb, and Total chlorophyll- TChl), leaf (LPROT) and stem protein (SPROT), carotenoids (CAR), and ascorbic acid (ASC) accumulation in plants of Asparagus racemosus. 

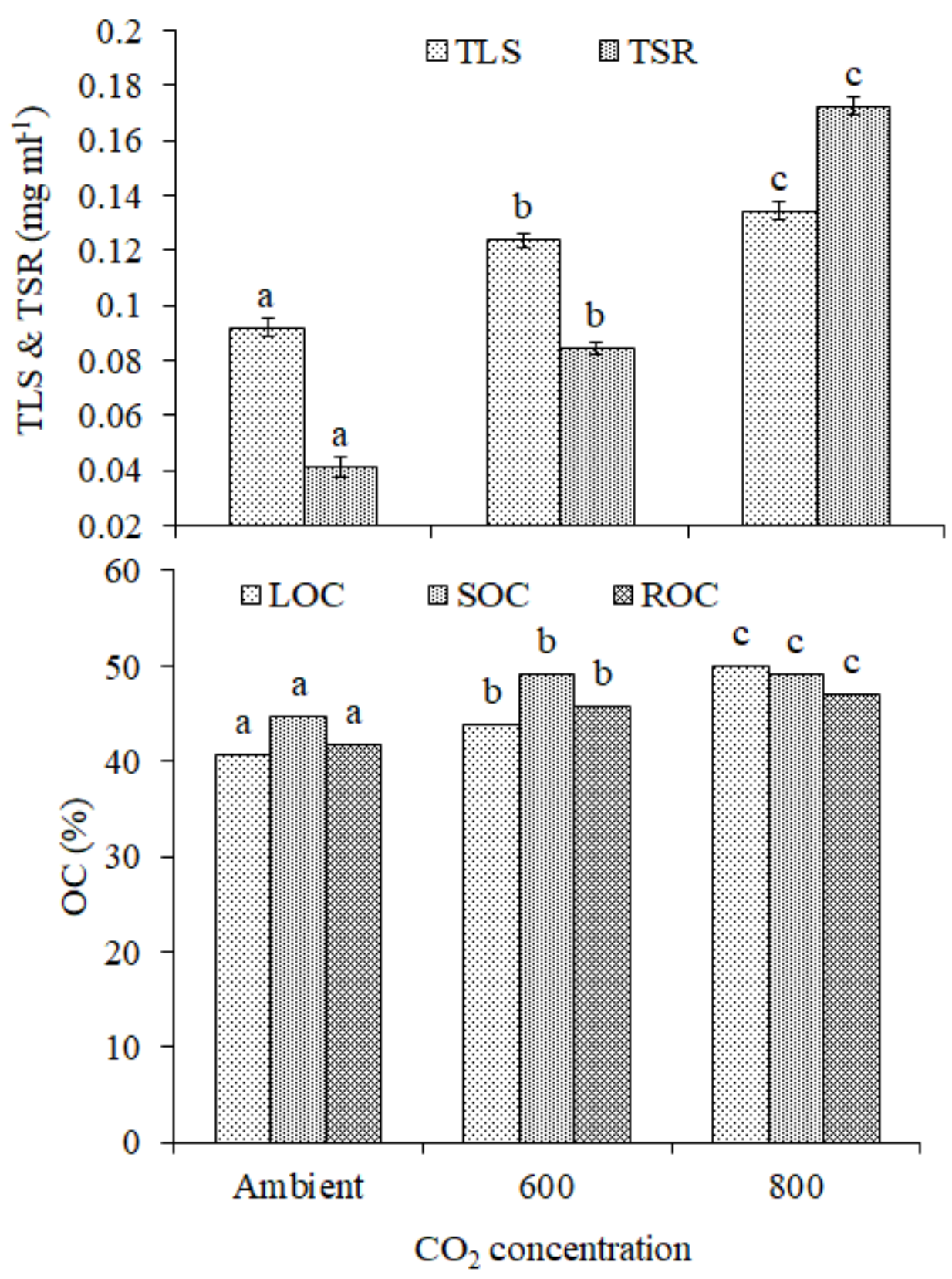

Figure 2

Effect of elevated CO2 concentration on total sugars in stem (TLS) and root (TSR), and organic carbon content in leaf (LOC), stem (SOC), and root (ROC) tissues of Asparagus racemosus. 

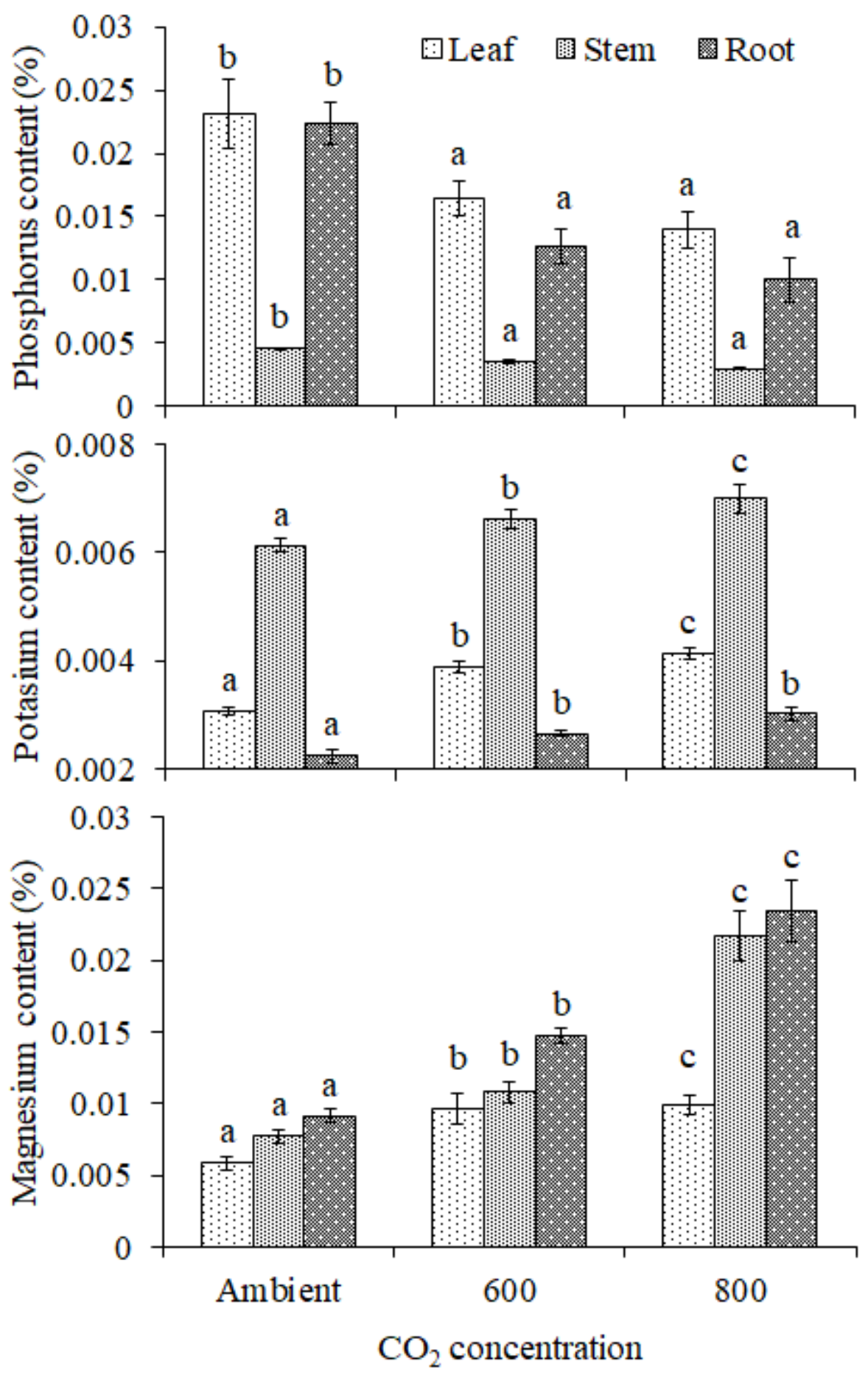

Figure 3

Effect of elevated $\mathrm{CO} 2$ concentration on nutrients partitioning n leaf, stem , and root tissues of Asparagus racemosus. 


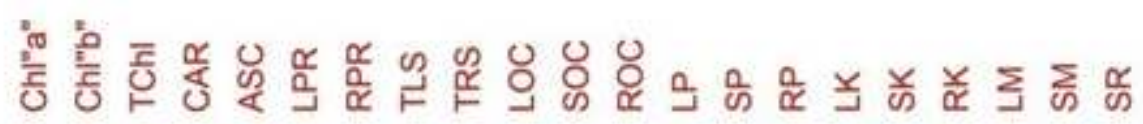

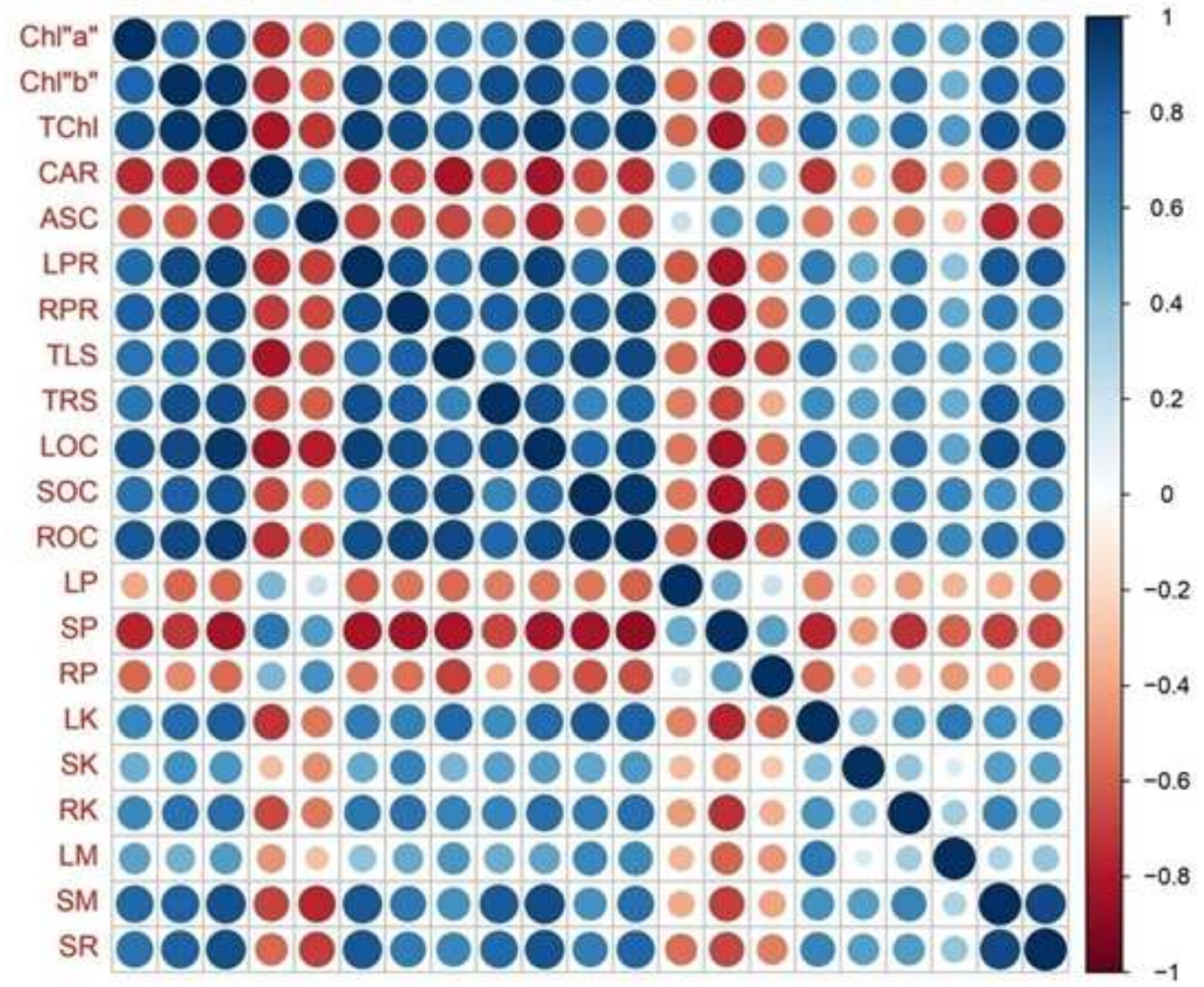

Figure 4

Correlation between biochemical and nutrients traits of Asparagus racemosus. 


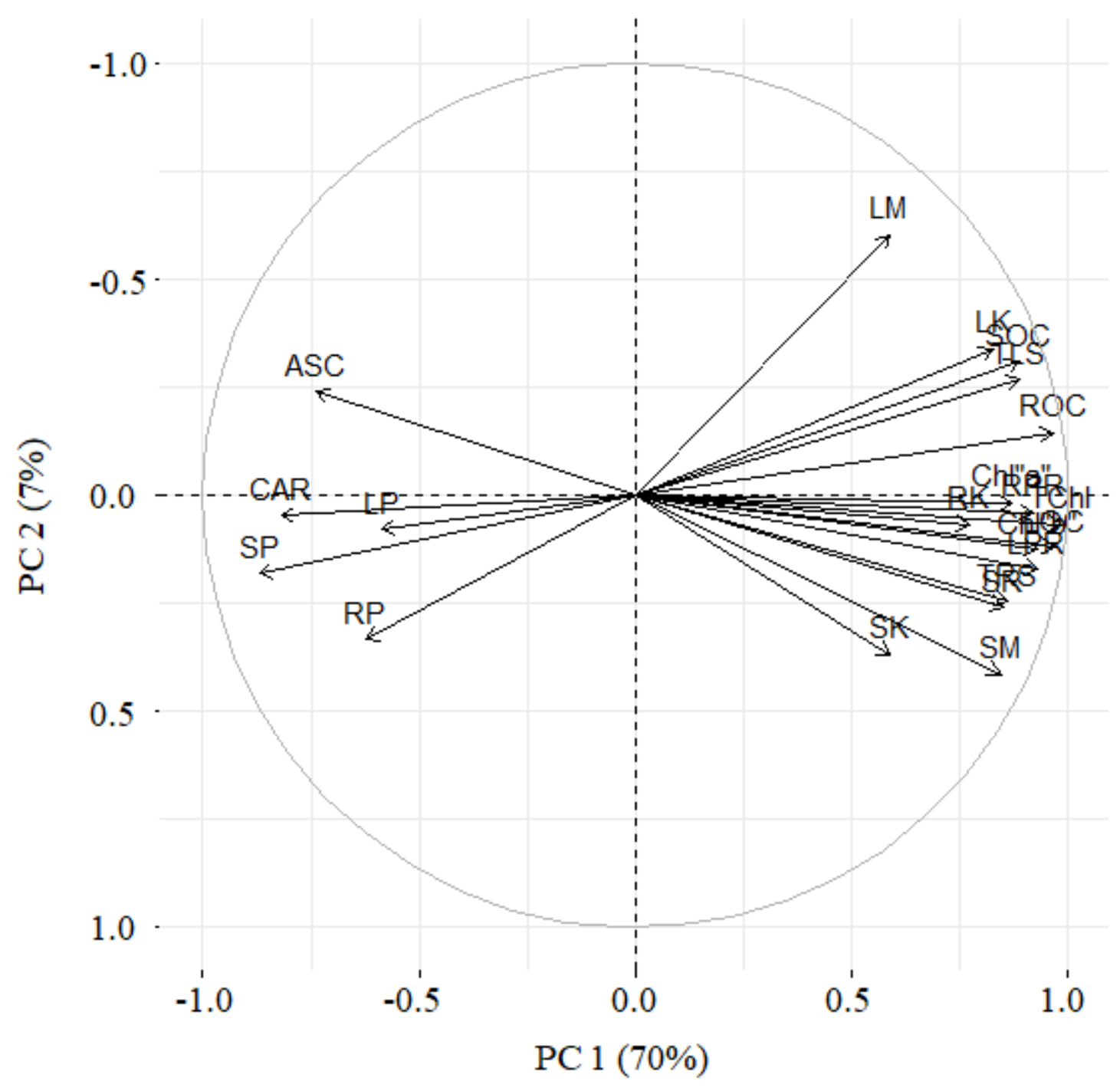

Figure 5

Princiapal component analysis of biochemical and nutrients traits of Asparagus racemosus.

\section{Supplementary Files}

This is a list of supplementary files associated with this preprint. Click to download.

- Tables1.docx 